\title{
BOREAL SPECIES MICROTUS AGRESTIS AND SICISTA BETULINA IN THE REGION OF THE UKRAINIAN CARPATHIANS: A REVIEW
}

\author{
Zoltán Barkaszi \\ National Museum of Natural History, NAS of Ukraine (Kyiv) \\ Bohdan Khmelnytsky St. 15, Kyiv, 01030 Ukraine \\ E-mail: zlbarkasi@ukr.net
}

\begin{abstract}
Boreal species Microtus agrestis and Sicista betulina in the region of the Ukrainian Carpathians: a review. - Barkaszi, Z. - The paper deals with the peculiarities of distribution of the field vole (M. agrestis) and the northern birch mouse (S. betulina) in the region of the Ukrainian Carpathians, which are the southern range edge of these species. The present review is based on results obtained by analysis of records and sightings of these species and over 220 collection samples have been examined from leading zoological museums of Ukraine. It has been revealed that the range of the field vole on the northern megaslope of the Ukrainian Carpathians (i.e. Ciscarpathia [=Prykarpattia] and, partly, Bukovina) is practically continuous up to the krummholz and subalpine zones where the species has the highest abundance. Its distribution extends further to the southern megaslope down to the zone of deciduous forests, but the species does not penetrate the adjacent plains. On the contrary, records and sightings of the northern birch mouse are associated with highland biotopes (subalpine meadows and krummholz) of central massifs, foremost of Chornohora and Gorgany, and partly of the Skole Beskids. Moreover, the spatial distribution of records of S. betulina is similar to insular at the southern edge of its geographical range.
\end{abstract}

Key words: vole, birch mouse, species distribution, range edge, Carpathians.

Бореальні види Microtus agrestis та Sicista betulina в регіоні Українських Карпат: огляд. - Баркасі, 3. - У праці розглянуто особливості поширення полівки темної (M. agrestis) та мишівки лісової (S. betulina) в регіоні Українських Карпат, що є південним краєм їхнього ареалу. В основі цього огляду покладено результати аналізу знахідок та спостережень цих видів, розглянуто понад 220 їх зразків iз провідних зоологічних музеїв України. Виявлено, що на північному макросхилі Українських Карпат (з боку Прикарпаття та частково Буковини) ареал полівки темної практично неперервний і досягає високогір'я, де ії чисельність найвища, а також поширюється далі на південний макросхил, до поясу широколистяних лісів, і не проникає на рівнини. Натомість, знахідки та спостереження мишівки лісової пов'язані з високогірними біотопами (субальпійські луки та криволісся) центральних гірських хребтів, насамперед Чорногори та Горган, частково й Східних Бескид. Крім того, просторовий розподіл знахідок S. betulina нагадує острівне поширення цього виду на південному краї його ареалу.

Ключові слова: полівка, мишівка, поширення видів, край ареалу, Карпати.

\section{Introduction}

Being situated in Central Europe, the Carpathian mountain system is a unique biogeographic island with a peculiar composition of biota. The biodiversity of the Carpathians is due to several factors. Foremost, because of their special geographic location - the Carpathian bow is a contact zone between faunal assemblages of the Pannonian Basin, the East European Plain, and the Balkans. Insularity, large extent and landscape heterogeneity are important factors that determine the features of modern composition of the region's biota (Mráz, Ronikier, 2016).

The Carpathian region was also an important refugium during Pleistocene glaciations where species associated with temperate climate coexisted with more cold-adapted ones (Sommer, Nadachowski, 2006; Schmitt, Varga, 2012). Obviously, all these features determine the high level of species richness (e.g. in mammals, nesting birds, amphibians, lichens, and vascular plants) and the significant number of endemic taxa (in particular among subterraneous invertebrates, mollusks, arthro- 
pods, and vascular plants) allowing to consider the Carpathian region an important biodiversity hotspot (Bálint et al., 2011; Barkasi, 2016; Mráz, Ronikier, 2016).

As a geographic barrier the Carpathians are part of range edges of several species, in particular mammals, that exist here in isolated (e.g., Lynx lynx, Ursus arctos) or semi-isolated (e.g., Eptesicus nilssonii) populations. For such boreal species as Microtus agrestis and Sicista betulina the Carpathians are the southern range edge, and the distribution of these species is related mainly to the presence of suitable habitats. Besides, both species are part of the montane assemblage of small mammals (Barkasi, Zagorodniuk, 2016).

The existence of species under such conditions is always accompanied with low population densities and a narrow niche, particularly regarding its spatial dimension. The species ecology at range edges is of particular interest because it gives insights into the factors that determine the limits of realized niche and the population dynamics. Species with low population densities are under a higher risk of extinction having decreased adaptive capabilities, which could inhibit or slow down range expansions and thus stabilize range edges (Bahn et al., 2006).

Differences in the intensity of influence of factors controlling population dynamics (environmental conditions, interspecific interactions) from the range center to its periphery, and also evolutionary factors that determine the species adaptive capability were used to explain the biological features of species existing in range edge conditions (Holt, Keitt, 2005; Bahn et al., 2006). However, despite the considerable number of proposed theoretic models, many issues regarding the relative importance of abiotic and biotic factors in determination of range limits remain unexplored due to difficulties in testing these theories in practice (Gaston, 2009; Sexton et al., 2009).

The aim of the present work is to analyze the distribution of boreal species for which the Carpathian mountain system represents the southern range edge. As model objects the Ukrainian part of the Carpathians and two rodent species - the field vole (Microtus agrestis) and the northern birch mouse (Sicista betulina) which are common for boreo-montane assemblages of the region - have been used.

\section{Material and methods}

The present contribution is based on results obtained by analysis of zoological collections of the National Museum of Natural History, NAS of Ukraine (NMNHU ${ }^{1}$ ), Laboratory of Population Ecology and Biogeography, Institute of Zoology, NAS of Ukraine (SIZK), State Museum of Natural History (SMNH), Zoological Museum of Taras Shevchenko Kyiv National University (ZMKU), and B. Dybowski Zoological Museum of Ivan Franko Lviv National University (ZMD).

While working with collection materials, 437 samples of voles from the Ukrainian Carpathians have been examined, data on which are summarized in our previous work. Among them, due to identification and re-identification, 221 samples of the field vole have been revealed. The only museum specimen of the northern birch mouse, known for the author, was collected in the Ukrainian Carpathians and it is being preserved in ZMD.

Data on several aspects of biology and distribution of the field vole and the northern birch mouse published in works of the region's researchers of the $20^{\text {th }}-21^{\text {st }}$ centuries have been also used and generalized. Cartographic materials have been prepared by QGis open-source geoinformation system application.

\section{Results and discussion}

\section{Field vole (Microtus agrestis)}

The field vole has been recorded in the fauna of the Carpathian region since the very first fauna surveys. For Ciscarpathia, in particular for Galicia and Bukovina, the field vole is listed in A. Zawadzki's review as Hypudaeus gregarius Illig. (Zawadzki, 1840). In the Carpathian Mountains M. agrestis was first recorded by L. Méhely (1908) as a result of re-identification of museum sam-

\footnotetext{
${ }^{1}$ Acronyms of the museums are given in accordance to Zagorodniuk, Shydlovskyy, 2014 and Akimov et al., 2016.
} 
ples collected in the former Hungarian county Árva (Hungarian: Árva vármegye), which today is part of Slovakia and Poland (Slovak: Orvská župa, Polish: Komitat Orawa).

The distribution of this rodent is related mainly to the presence of suitable habitats with boreal vegetation elements and microclimatic conditions. The field vole is distributed in the lowlands in the western regions of Ukraine. Its typical biotopes in Ciscarpathia are open moist meadows in the Dniester river's valley (Tatarinov, 1956). In the 1950s, the species was first recorded in the mountainous part of Bukovina (Horbyk, 1956). Its typical biotopes in the Carpathian Mountains are fir-spruce forests, krummholz and subalpine meadows, where it occupies moist habitats close to streams (Tatarinov, 1956; Grodziński et al., 1966; Uhrin et al., 2009; Nae et al., 2010). The highest abundance of the field vole in the Ukrainian Carpathians is in the zone of krummholz (Kyselyuk, 2002), mainly in thickets of the creeping pine (Pinus mugo) and docks (Rumex spp.) (Rudyshin, 1965). There is a decline in the abundance of this species on the southern megaslope and its records from the lowland part of Transcarpathia (= Zakarpattia) are unknown (Tatarinov, 1956; Korchinsky, 1988).

Seasonal migrations of the field vole in the subalpine zone of Chornohora were well studied by B. Pyliavsky (Pyliavsky, 1970). It was shown that its populations are the most sedentary during summer and winter, while migration occurs in spring and autumn. Thus, in spring the field vole starts to migrate to the polonynas ${ }^{2}$ in the late May. In this time, they appear in thickets of matgrass, blueberry, and hair grass. During June-July, the abundance of the field vole in these associations is quite high and it fluctuates slightly. However, in early August the number of these animals sharply declines and continues to decrease to late autumn in accordance to the changes of vegetation aspects. Autumn migrations are the most clearly expressed, probably because of poor feeding conditions on the polonynas and of sharp temperature drop accompanied by frequent and strong winds.

According to Pyliavsky (1970), the reason for the field vole's migration in the subalpine zone is the change of vegetation aspects and the decline of food on the polonynas, which causes the migration of these rodents from the polonyna to the forest. In spring, when the vegetation starts to develop on the polonynas, these voles migrate in the opposite direction. In summer these animals migrate to short distances, however, along with the development of vegetation in other associations the route passed by the voles is notably increases.

Data from literature on the distribution of the field vole in the Ukrainian Carpathians are confirmed by the analyzed museum collections. There are 221 specimens of $M$. agrestis from the region of the Ukrainian Carpathians in the five museums from the following locations ${ }^{3}$ (number of specimens in parentheses):

ZMKU (19): NAD, Hoverla Mt., northern slope (2); RAK, Baltsatul pol. ${ }^{4}$ (1), Hoverlianka tract (4); - TIA, Bradul tract (11), Popadia Mt. (1).

SIZK (13): $\$ NAD, Maryshevska pol. (8), ivo ${ }^{4}$ Mykulychyn vil. (1); RAK, Breskul pol. (4).

SMNH (76): $\downarrow$ DOL, ivo Vyshkiv vil. (11); NAD, Pozhyzhevska pol. (39), Kukul Mt. (2), ivo Vorokhta city (1); RAK, Breskul pol. (1), Petros Mt. (1), Baltsatul pol. (1), Kvasivskyi Menchul pol. (4), Sheshul Mt. (4); ROZ, ivo Osmoloda vil. (2); SAM, ivo Kornalovychi vil. (4); SKO, ivo Skole city (1); - VER, Chyvchyny Mts. (2), ivo Dzembronia vil. (2), Smotrych pol. (1).

ZMD (34): DOL, ivo Vykhoda u.t.s. ${ }^{3}$ (1); $\$ IRS, ivo Dovhe vil. (4), Lypove tract (2); NAD, Hadzhyna pol. (1); RAK, Baltsatul pol. (4), Kvasivskyi Menchul pol. (1), Lysycha pol. (2), Sheshul Mt. (15), Vesniarka pol. (1); $\downarrow$ VER, Hostiv Mt. (2); VOL, Borzhava pol. (1).

NMNHU (79): BOH, ivo Bohorodchany city (47); DRO, ivo Drohobych city (1); HAL, ivo Ozeriany vil. (5); HOR, ivo Berezets vil. (2); PER, Runa pol. (4); RAK, ivo Kvasy vil. (16); STR, ivo Strilkiv vil. (2); TIA, ivo Velyka Uholka vil. (1); ivo Chernivtsi city (1).

\footnotetext{
${ }^{2}$ Polonyna is the local name of subalpine meadows and pastures (both of natural and artificial origin).

${ }^{3}$ Acronyms of districts (= raions; here and further): BOH - Bohorodchany; DOL — Dolyna; DRO — Drohobych; HAL - Halych; HOR - Horodok; IRS - Irshava; MIZ - Mizhhiria; NAD - Nadvirna; PER - Perechyn; RAK — Rakhiv; ROZ — Rozhniativ; SAM — Sambir; SKO — Skole; STR — Stryi; TIA — Tiachiv VER — Verkhovyna; VOL - Volovets.

${ }^{4}$ Abbreviations used: pol. — polonyna; ivo — in vicinities of; vil. — village, u.t.s — urban-type settlement.
} 


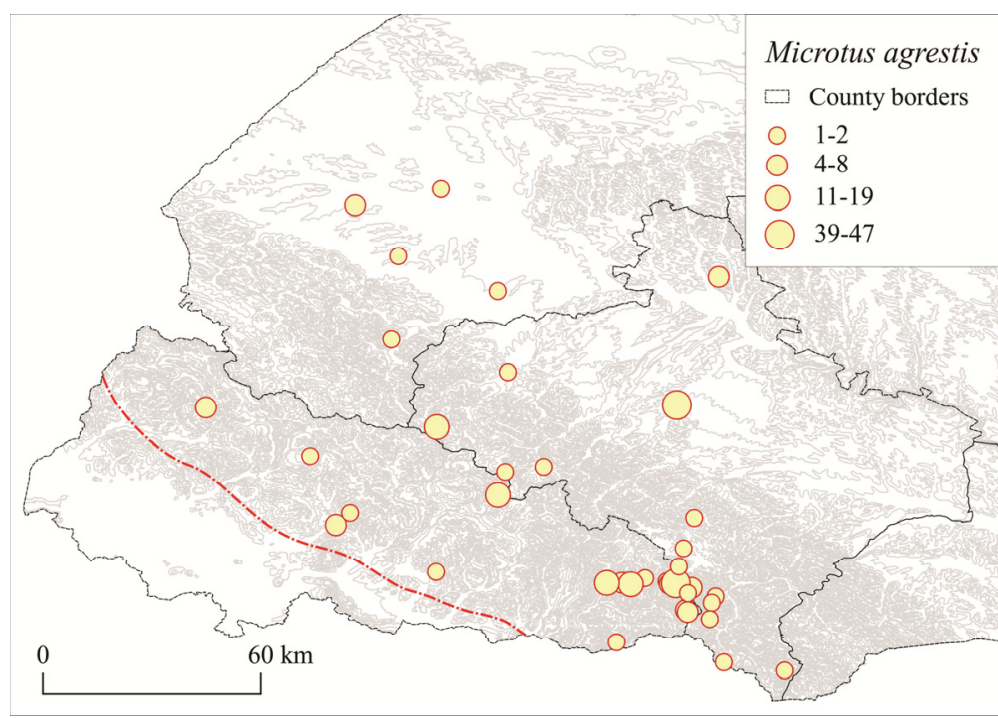

Fig. 1. Records of the field vole (M. agrestis) in the region of the Ukrainian Carpathians. The dash-dot line indicates the southern range edge of the species.

Рис. 1. Знахідки полівки темної (M. agrestis) в регіоні Українських Карпат. Штрих-пунктирна лінія позначає південний край ареалу виду.

By combination of data on record localities obtained from literature sources and from the collections, the distribution map of the field vole in the region of the Ukrainian Carpathians has been created (fig. 1).

\section{Northern birch mouse (Sicista betulina)}

During the Middle and Late Pleistocene the distributional range of the genus Sicista was notably enlarged westward (Oppliger, Becker, 2010; Rofes et al., 2012). Today the representatives of this genus in the fauna of Europe are extremely rare. After introducing the technique of studying of chromosomal slides into the practice of zoological research, it was revealed that the European species of birch mice actually represent species complexes "Sicista betulina" and "Sicista subtilis." Forms (species) distinguished by cytogenetic features were established in each complex during the last three decades (Sokolov et al., 1987; Zagorodniuk, Kondratenko, 2006).

The main distribution area of Sicista betulina includes coniferous forests (taiga) of the eastern Palearctic: from the Czech Republic and Poland to the Baikal, and from the Arctic Circle to the Carpathian Mountains (Pucek, 1999; Shenbrot et al., 2008). Some isolated relict populations of the species exist also in Scandinavia, northern Germany, and Austria (Pucek, 1999; Meinig et al., 2008). The northern birch mouse was first recorded in the fauna of the Carpathians in 1913 and described as Sicista montana Méh. based on specimens from the High Tatras and mountains of the former Árva county (Méhely, 1913). In the fauna of the western regions of Ukraine, the species was first recorded in 1953 based on two specimens trapped in Rakhiv raion, Transcaprathia (Koliushev, 1953).

Cytogenetic studies showed that the Carpathian (just as the Polissian) population of the northern birch mouse refers to the $2 \mathrm{n}=32$ chromosome race (Baskevich, 1988; Baker et al., 1996; Zagorodniuk, 2007) and represents the taxon Sicista betulina s. str. (Zagorodniuk, Kondratenko, 2006). The Carpathian form is quite often considered a separate subspecies Sicista betulina montana Méh. (Zagorodniuk, 1998; Zagorodniuk, Kondratenko, 2006).

The northern birch mouse is a rare and infrequent species in the Ukrainian Carpathians with a sporadic distribution. It is associated with krummholz and other subalpine vegetation (Tatarinov, 1956). The species is also rare in the Polish (Grodziński et al., 1966), Slovakian (Štollmann, 1984; Uhrin et al., 2009), and Romanian (Murariu, 1997) parts of the Carpathians. The idea that the Carpathians are the southern range edge of Sicista betulina was proposed already in the middle 1990s, in particular by Korchinsky (1995) and Murariu (1997).

Most of the records of the northern birch mouse originate from the Chornohora massif, in particular from Pozhyzhevska polonyna (Tatarinov, 1956; Rudyshin, 1982). The species is poorly studied compared to other rodent species of the region, and its biological and ecological features were 
described in the middle of the $20^{\text {th }}$ century based on single records from Chornohora (Koliushev, 1953; Turyanin, 1959; Tatarinov, 1973). The northern birch mouse is a poorly studied species in the neighboring regions as well (Pelikan et al., 1979).

The northern birch mouse hibernates in winter, which influences such aspects of biology as seasonal activity and feeding. It was revealed that under conditions of the Carpathians the northern birch mouse is active from April to October (Pelikan et al., 1979). Its highest activity in the Ukrainian Carpathians covers June-August, and the latest trappings are known for the late September. Due to the relatively short period of activity, the northern birch mouse reproduces only once a year (Rudyshin, 1982).

The feeding of this rodent is closely related to the peculiarities of existence under conditions of montane habitats. According to its trophic connections in Carpathian biogeocenoses, the northern birch mouse is both a predator and an herbivore. According to data of Rudyshin (1982) on the gastric content of 35 examples, $65.4 \%$ of the food is made up from animal components (mainly insects), while $34.5 \%$ from plant components. The animal food components mainly consisted of leaf beetles $(25.6 \%)$, ground beetles $(26.7 \%)$, and larvae of flies $(24.5 \%)$. The prevalence of animal components in the diet of the birch mouse is apparently related to the necessity of accumulation enough nutrients essential for winter hibernation during a relatively short period of activity and high abundance of insects in the subalpine zone.

The museum specimen of the northern birch mouse has been analyzed, as well as separate publications dealing with data on record and sighting localities of the species. Based on combination of all available data, the distribution map of Sicista betulina in the Ukrainian Carpathians has been created (fig. 2). In total 106 specimens and sightings of the species are known from 9 locations:

ZMD (1): NAD, Pozhyzhevska pol. (1).

Rudyshin, 1982 (93): NAD, Pozhyzhevska pol. (92); Breskul pol. (1).

Stetsula, 2011 (1): SKO, Skole Forestry (1).

Koliushev, 1953 (2): RAK, Hoverla Mt. (1); Kozmeschyk tract (1).

Zagorodniuk I., pers. com. (5): $\downarrow$ RAK, Maryshevska pol. (5).

Mateleshko O., pers. com. (2): MIZ, Synevir Lake, bank (1); $\downarrow$ RAK, Apshynets Lake, bank (1).

Tsapulich O., pers. com. (1): RAK, Maryshevska pol. (1).

Palameranko O., pers. com. (1): SKO, Parashka Mt. (1).

\section{The geography of records}

Analysis of the geography of records of the studied species clearly confirms the theory that the Carpathians, in particular the Ukrainian Carpathians, are the southern range edge of these species. In case of M. agrestis we can observe its distribution from the western forest zone of Ukraine to the Carpathians. The clearest distributional corridor is the Polissia-Roztochia-Ciscarpathia-Carpathians direction, which connects the Carpathian population with the main range of the species in the forest zone of Eastern Europe. On the northern megaslope of the Ukrainian Carpathians (from the side of Ciscarpathia and partly of Bukovina), the field vole is distributed up to the subalpine zone having a continuous range. On the contrary, on the southern megaslope, i.e. in Transcarpathia, the species' range is sharply ragged, and most of the records are related to mountain communities, while there are no records from the lowlands.

The spatial distribution of records of M. agrestis in the Ukrainian Carpathians is clearly associated with the biogeographic peculiarities of this region, including the differences in altitudinal zonation and related geobotanical conditions on the northern and southern megaslopes. The northern megaslope is characterized by mainly boreal type of plant cover with a high fraction of mixed forests from the foothills up to the tree line. On the contrary, there is a gradual alternation of zones of krummholz, dark coniferous, mixed, and deciduous forests with the decrease of the elevation on the southern megaslope. In addition, an important factor is the dense network of river valleys on both megaslopes that also promote the distribution of species associated with humid habitats, such as the field vole. 


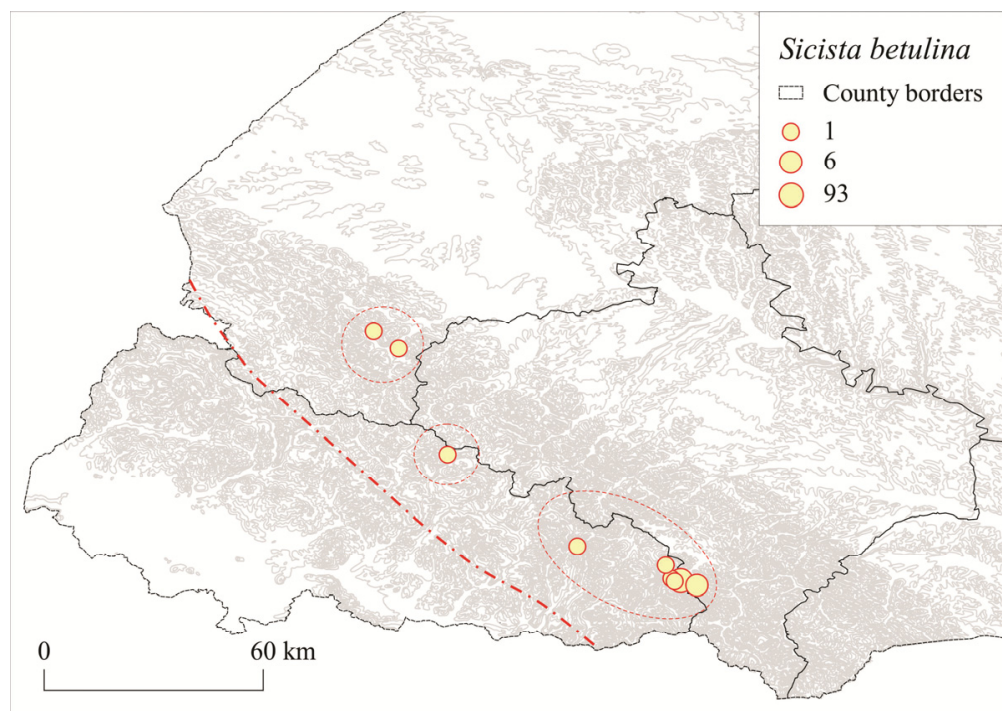

Fig. 2. Records of the northern birch mouse (S. betulina) in the region of the Ukrainian Carpathians. The dash-dot line indicates the southern range edge of the species.

Рис. 2. Знахідки мишівки лісової (S. betulina) в регіоні Українських Карпат. Штрих-пунктирна лінія позначає південний край ареалу виду.

In terms of the altitudinal zonation in the Ukrainian Carpathians, it should be noticed that most of the records of $M$. agrestis are related to the zones of krummholz and subalpine meadows (polonynas), as well as of coniferous and mixed forests. In the foothills of the southern megaslope and in the Transcarpathian plain this vole has not been recorded. It allows suggesting that the range edge of this species in the Ukrainian Carpathians reaches the zone of deciduous forests on the southern megaslope.

Regarding to $S$. betulina, there are reasons to suggest that its Carpathian population, similarly to the field vole, might have a connection with the main geographical range through Roztochia and Polissia. Records and sighting of this species in the Ukrainian Carpathians are known from the northern megaslope and some central massifs such as Gorgany and Chornohora. Based on recent observations it can be suggested that on the southern megaslope the northern birch mouse is distributed only at high elevations and it does not occur below the tree line zone. Therefore, it can be assumed that the southern range edge of this species corresponds to the zones of subalpine meadows and krummholz of the central ridges of the Ukrainian Carpathians.

The low population abundance of the northern birch mouse at the southern range edge is likely related to its more limited adaptive capability compared to the field vole, however, this rodent is considered rare throughout its whole range. The rarity of this species is probably associated with its ecological peculiarities. In particular, the short period of activity and long-term hibernation in overly cold conditions might be reasons for the death of these animals during winter (lack of food storages for winter, shortage of nutrients accumulated during a short warm period for a long-term hibernation, freezing due to low temperatures). Thus, the only generation for a season, critical conditions of hibernation with a likely high level of mortality, and limited habitat restriction of this species all are unfavorable factors for population growth.

\section{Conclusions}

The Ukrainian Carpathians are the southern range edge of several boreal species, in particular of the field vole (Microtus agrestis) and the northern birch mouse (Sicista betulina), which are also part of bore-montane assemblages in the region's fauna.

The analysis of records and sightings of these two species in this region shows that the field vole has a continuous range on the northern megaslope, while on the southern megaslope its range is sharply ragged and it does not rich the lowlands. Regarding to the northern birch mouse, the highest concentration of its record and observation localities is related to highland biotopes (subalpine meadows, krummholz) of Chornohora, Gorgany, and the Skole Beskids. Such distribution pattern of the species' record localities at its southern range edge is similar to insular. 
The narrow ecological niche with limited spatial component and associated features of spatial distribution of these species' populations well illustrate and may have key importance for understanding the patterns of biogeography of montane faunal assemblages.

\section{Acknowledgements}

The author expresses his gratitude to Yevgenia Uliura (National Museum of Natural History, Kyiv), Zhanna Rozora (Zoological Museum of Taras Shevchenko Kyiv National University), Andrii Zatushevskyi (Zoological Museum of Ivan Franko Lviv National University), Irina Syniavska and Sergii Rebrov (Institute of Zoology, NAS of Ukraine, Kyiv) for the help and assistance they provided while working with the collections. The author also would like to acknowledge Mykhailo Krynytskyi (Head of the Department of Forestry and Wildlife Management, Dovhe Forestry and Game Husbandry) for his kind help in clarifying a number of important record localities. A special thanks to Igor Zagorodniuk for his participation in planning and discussion of this investigation, as well as to Oleksandr Kovalchuk for proofreading the manuscript.

\section{References • Література}

Akimov, I. A., Kharchenko, V. O., Puchkov, A. V. et al. Scientific fund collections of I. I. Schmalhausen Institute of Zoology, NAS of Ukraine // Proceedings of the National Museum of Natural History. 2016. Vol. 14. P. 95-108. (in Ukr.)

[Акімов, I. А., Харченко, В. О., Пучков, О. В. та ін. Наукові фондові колекції Інституту зоології ім. І. І. Шмальгаузена НАН України // Вісник Національного науково-природничого музею. 2016. Том 14. С. 95-108.]

Bahn, $V$., O'Connor, R. J., Krohn, W. B. Effect of dispersal at range edges on the structure of species ranges // Oikos. 2006. Vol. 115. P. 89-96.

Baker, R. J., Hamilton, M. J., Van Den Bussche, R. A. et al. Small mammals from the most radioactive sites near the Chornobyl nuclear power plant // Journal of Mammalogy. 1996. Vol. 77, No. 1. P. 155-170.

Bálint, M., Ujvárosi, L., Theissinger, K. et al. The Carpathians as a major diversity hotspot in Europe // Biodiversity Hotspots / Zachos, F. E., Habel, J. C. (eds.). Berlin; Heidelberg : Springer, 2011. P. 189-205.

Barkasi, Z. Endemism in the mammalian fauna of the Carpathians // Proceedings of the Theriological School. 2016. Vol. 14. P. 3-15.

Barkasi, Z. L., Zagorodniuk, I. V. Spatial distribution of the micromammal fauna in the Ukrainian Carpathians // Regional Aspects of Floristic and Faunistic Research : Proceedings of the Third International Conference / Ed. by I. V. Skilsky, A. V. Yuzyk. Chernivtsi : Druk Art, 2016. P. 5-11.

Baskevich, M. I. Khromosomnye nabory nekotorykh vidov gryzunov iz tsentralnoy chasti Vostochnykh Karpat // Gryzuny: Tezisy dokladov VII Vsesoyuz. soveschaniya. Sverdlovsk : UrO AN SSSR, 1988. Vol. 1. P. 60-61. (in Rus.) [Баскевич, М. И. Хромосомные наборы некоторых видов грызунов из центральной части Восточных Карпат // Грызуны: Тезисы докладов VII Всесоюзного совещания. Свердловск : УрО АН СССР, 1988. Том 1. С. 60-61.]

Gaston, K. J. Geographic range limits achieving synthesis // Proceedings of the Royal Society B. 2009. Vol. 276. P. 1395-1406.

Grodziński, W., Górecki, A., Janas, K., Migula, P. Effect of rodents on the primary productivity of alpine meadows in Bieszczady Mountains // Acta Theriologica. 1966. Vol. 11, No. 20. P. 419-431.

Holt, R. D., Keitt, T. H., Lewis, M. A. et al. Theoretical models of species' borders: single species approaches // Oikos. 2005. Vol. 108. P. 18-27.

Horbyk, P. V. Do ekolohii polivky temnoi na Bukovyni // Zbirnyk prats Zool. muzeiu. 1956. No. 27. P. 165-168. (in Ukr.)
[Горбик, П. В. До екології полівки темної на Буковині // Збірник праць Зоологічного музею. 1956. № 27. С. 165168.]

Koliushev, I. I. Kratkiy ocherk fauny gryzunov Zakarpatskoy oblasti // Nauchnye zapiski Uzhgorodskogo universiteta. 1953. Vol. 8. P. 143-189. (in Rus.)

[Колюшев, И. И. Краткий очерк фауны грызунов Закарпатской области // Научные записки Ужгородского университета. 1953. Т. 8. С. 143-189.]

Korchinsky, A. Gryzuny Ukrainskikh Karpat // Voprosy okhrany i ratsionalnogo ispolzovaniya rastitelnogo i zhivotnogo mira Ukrainskikh Karpat. Uzhgorod: MOIP, 1988. P. 156173. (in Rus.)

[Корчинский, A. Грызуны Украинских Карпат (итоги исследования) // Вопросы охраны и рационального использования растительного и животного мира Украинских Карпат. Ужгород : МОИП, 1988. С. 156-173.]

Korchinsky, O. Osoblyvosti poshyrennia hryzuniv v Ukrainskykh Karpatakh // Tezy dop. 49 nauk. konf., prysv. 50-rich. UzhDU. Ser. Biologia. Uzhgorod, 1995. P. 48. (in Ukr.) [Корчинський, О. В. Особливості поширення гризунів в Українських Карпатах // Тези доп. 49-ої наук. конф., присв. 50-річчю УжДУ. Сер.: Біологія. Ужгород, 1995. C. 48.]

Kyselyuk, $O$. The population of small mammals of forest ecosystems of the Ukrainian Carpathians northeast macroslopes // Journal of Luhansk State Pedagogical University. Series Biological Sciences. 2002. No. 45. P. 15-18. (in Ukr.) [Киселюк, О. I. Населення дрібних ссавців лісових екосистем північно-східного макросхилу Українських Карпат // Вісник Луганського державного педагогічного університету. Серія Біологічні науки. 2002. № 45. С. 15-18.]

Méhely, L. Két új poczokfaj a magyar faunában // Állattani közlemények. 1908. 7 kötet, 1 füzet. 3-14 o.

Méhely, L. Az emlősök faji criteriuma // Állattani közlemények. 1913. 12 kötet, 2 füzet. 65-72 o.

Meinig, H., Zagorodnyuk, I., Henttonen, H. et al. Sicista betulina // The IUCN Red List of Threatened Species, version 2017. http://www.iucnredlist.org (accessed on 31 May 2017).

Mráz, P., Ronikier, M. Biogeography of the Carpathians: evolutionary and spatial facets of biodiversity // Biological Journal of the Linnean Society. 2016. Vol. 119. P. 528-559.

Murariu, D. Le siciste de bouleaux (Sicista betulina) Pallas, 1779 - Rodentia, Zapodidae) dans les Monts Rodna // Travaux du Muséum National d'Histoire Naturelle "Grigore Antipa". 1997. Vol. 37. P. 147-157.

Nae, I., Cobzaru, I., Cozma, A. M. New data concerning the 
small mammal fauna (Insectivora, Rodentia) from the Rodna Mountains National Park (Eastern Carpathians, Romania) // Transylvanian Review of Systematical and Ecological Research. 2010. Vol. 9. P. 193-204.

Oppliger, J., Becker, D. Morphometrical analyses of northern Birch Mice (Sicista betulina Pallas, 1779; Mammalia; Rodentia) discovered in a rich locality from the Late Pleistocene of northwestern Switzerland // Comptes Rendus Palevol. 2010. Vol. 9. P. 113-120.

Pelikan, J., Gaisler, J., Rödl, F. Naši savci. Praha, 1979. 169 s.

Pucek, Z. Sicista betulina (Pallas, 1779) // The atlas of European mammals / Ed. by Mitchell-Jones, A. J., Amori, G., Bogdanowicz, W. et al. London: Academic Press, 1999. P. 304-305.

Pyliavsky, B. R. Seasonal migrations of Microtus agrestis L. on subalpine meadows of Chornohora of the Ukrainian Carpathians. Communications II // Vestnik zoologii. 1970. No. 1. P. 51-60. (in Rus.)

[Пилявский, Б. Р. Сезонные миграции пашенной полевки (Microtus agrestis L.) на субальпийских лугах Черногоры Украинских Карпат. Сообщение II // Вестник зоологии. 1970. №. 1. C. 54-60.]

Rofes, J., Garcia-Ibaibarriaga, N., Murelaga, X. et al. The southwesternmost record of Sicista (Mammalia; Dipodidae) in Eurasia, with a review of the palaeogeography and palaeoecology of the genus in Europe // Palaeogeography, Palaeoclimatology, Palaeoecology. 2012. Vol. 348-349. P. 6773.

Rudyshin, M. P. Melkiye mlekopitayuschiye Chivchinskikh gor// Flora i Fauna Ukrainskykh Karpat: Tezy dop. mizhvuz. konf. Uzhgorod, 1965. P. 109-110. (in Rus.)

[Рудышин, М. П. Мелкие млекопитающие Чивчинских гор // Флора і фауна Українських Карпат: Тези доп. міжвуз. конф. Ужгород, 1965. С. 109-110.]

Rudyshin, M. P. K ekologii karpatskoy populyatsii lesnoy myshovki // Vestnik zoologii. 1982. No. 2. P. 63-65. (in Rus.)

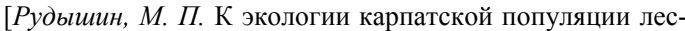
ной мышовки // Вестник зоологии. 1982. № 2. С. 63-65.]

Schmitt, T., Varga, Z. Extra-Mediterranean refugia: The rule and not the exception // Frontiers in Zoology. 2012. Vol. 9. P. 22.

Shenbrot, G. I., Sokolov, V. E., Heptner, V. G., Koval'skaya, Y. $M$. Jerboas, Mammals of Russia and Adjacent Regions. Washington : Smithsonian Institution Libraries, 2008. 768 p.

Sexton, J. P., McIntyre, P. J., Angert, A. L., Rice, K. J. Evolution and ecology of species range limits // Annual Review of Ecology, Evolution, and Systematics. 2009. Vol. 40. P. 415436.

Sokolov, V. E, Kovalskaya, Yu. M., Baskevich, M. I. Review of karyological research and the problems of systematics in the genus Sicista (Zapodidae, Rodentia, Mammalia) // Folia Zoologica. 1987. Vol. 36, No. 1. P. 35-45.

Sommer, R. S., Nadachowski, A. Glacial refugia of mammals in Europe: evidence from fossil records // Mammal Review. 2006. Vol. 36, No. 4, P. 251-265.

Stollmann, A. Terrestrial small mammals in the Čergov Mountains (Western Carpathians, Czechoslovakia) // Miscellanea Zoologica Hungarica. 1984. T. 2. P. 13-14.
Tatarynov, $K$. A. Zviri Zakhidnykh Oblastei Ukrainy. Kyiv: Vyd. AN UkrRSR, 1956. 188 p. (in Ukr.)

[Татаринов, К. А. Звірі західних областей України. Київ : Вид-во АН Укр. РСР, 1956. 188 с.]

Tatarynov, K. A. Fauna Khrebetnykh Zakhodu Ukrainy: Ekolohiia, Znachennia, Okhorona. Lviv : Vyd. Lvivskoho Universytetu, 1973. 258 p. (in Ukr.)

[Татаринов, K. A. Фауна хребетних заходу України: екологія, значення, охорона. Львів : Вид-во Львівського університету, 1973. 258 с.]

Turyanin, I. I. Fauna, khozyaystvennoe i epidemiologicheskoe znacheniye gryzunov Zakarpatskoy oblasti // Nauchnye zapiski Uzhgorodskogo universiteta. 1959. Vol. 40. P. 2128. (in Rus.)

[Турянин, И. И. Фауна, хозяйственное и эпидемиологическое значение грызунов Закарпатской области // Научные записки Ужгородского университета. 1959. Том 40. C. 21-28.]

Uhrin, M., Benda, P., Ambros, M. et al. K faune hmyzožravcov (Erinaceomorpha, Soricomorpha) a hlodavcov (Rodentia) Národného parku Muránska planina a blízkeho okolia (stredné Slovensko) // Lynx, n. s. Praha. 2009. Vol. 40. P. 95-114.

Zagorodniuk, I. V. Endemic mammals fauna of the Carpathians: taxonomic structure and biogeographic analysis // The Carpathian region and problems of sustainable development. Proc. Intern. Conf. Rakhiv, 1998. P. 218-222. (in Ukr.) [Загороднюк, I. B. Ендемічна теріофауна Карпат: таксономічний та біогеографічний аналіз // Карпатський регіон і проблеми сталого розвитку. Мат. міжнар. конф. Рахів, 1998. Том 2. С. 218-222.]

Zagorodniuk, I., Kondratenko, O. Sicista severtzovi and its relatives in rodent fauna of Ukraine: cytogenetic and biogeographical analysis // Proceedings of the Theriological School. 2006. Vol. 7. P. 67-74. (in Ukr.)

[Загороднюк, I., Кондратенко, O. Sicista severtzovi та близькі до неї форми гризунів в Україні: цитогенетичний та біогеографічний аналіз // Праці Теріологічної Школи. 2006. Вип. 7. С. 67-74.]

Zagorodniuk, I. V. Allospecies of rodents of the group Sicista "betulina": spatial relationships in the context of the concept of limiting similarity // Visnyk of Dnipropetrovsk University. Series Biology, Ecology. 2007. No. 15. P. 45-53. (in Ukr.)

[Загороднюк, I. B. Аловиди гризунів групи Sicista "betulina": просторові взаємини з огляду на концепцію лімітувальної схожості // Вісник Дніпропетровського університету. Серія Біологія, Екологія. 2007. Вип. 15. C. 45-53.]

Zagorodniuk, I., Shydlovskyy, I. Acronyms for zoological collections of Ukraine // Zoological Collections and Museums (Collection of scientific articles) / Ed. by I. Zagorodniuk. Kyiv, 2014. P. 33-43. (in Ukr.)

[Загороднюк, I., Шидловський, I. Акроніми назв найбільших зоологічних колекцій України при позначеннях зразків // Зоологічні колекції та музеї : збірник наукових праць / За ред. І. Загороднюка. Київ, 2014. С. 33-43.]

Zawadzki, A. Fauna der Galizisch-Bukowinischen Wirbelthiere. Stuttgart : E. Schweizerbart Verlagshardlung, 1840. $195 \mathrm{~s}$. 